\title{
Voice Behavior and Career Success: The Moderating Role of Supervisor Attribution Motives
}

\author{
Jen-Wei Cheng*, Yi-Tai Seih, Cheng-Ze Hung, Tzu-Wei Su \\ Department of Business Administration, National Taiwan University of Science and Technology, Taiwan
}

Copyright $(2016$ by authors, all rights reserved. Authors agree that this article remains permanently open access under the terms of the Creative Commons Attribution License 4.0 International License

\begin{abstract}
This paper aims to develop a model delineating the relationship between altruistic concern for prosocial motives/felt accountability for impression management motives of voice behavior and employees' career success. The model proposed in this study argues that the relationship between motives and career success depends on the voice behavior mediating mechanism and the moderating effect of supervisor-attributed motives on the relationship between voice behavior and career success. The results stress the importance of the context of supervisor attribution motives in linked voice behavior and career success. Overall, our model attempts to address these concerns by highlighting in particular the role of the perspective of supervisor attribution motives to advance the body of knowledge about voice behavior and career success. Practical and theoretical implications are addressed on the basis of the research findings as well as suggestions for future research in the employee voice behavior field.
\end{abstract}

Keywords Altruistic Concern for Prosocial Motives, Felt Accountability for Impression Management Motives, Voice Behavior, Career Success

\section{Background/Objectives and Goals}

Career development is a dynamic process in the organization and individual perceived organizational career management to improve job performance and career satisfaction (Guan, Zhou, Ye, Jiang \& Zhou, 2015; Shen, Demel, Unite, Briscoe, Hall, Chudzikowski, \& Fei, 2015). In 2013, Taiwan's official data revealed that the army was downsized by more than $20 \%$. The organization re-engineering process generated a need for a flatter organizational structure, which was considered inefficient by some middle-management positions. In this condition, some all-volunteer forces (AVF) experienced a career plateau and faced fewer opportunities for upward promotion (McGovern, Hope-Hailey \& Stiles, 1998; Cheng \& Su, 2013). To make military labor force effective, military personnel policies should have diverse factors, such as pay, education, training, non-monetary compensation, quality of life, and promotion (Meese, 2002). Specifically, promotion is the most important indicator of career success in the AVF.

Scholars have discussed the AVF either as "good soldiers" who desire to help their supervisors or co-workers because of prosocial motives (e.g., altruistic concern: individuals who purposefully initiate the first step in being altruistic) or as "good actors" who are motivated to engage in citizenship with impression management to complete the task assigned by the supervisor (e.g., felt accountability for impression management motives: individuals with greater motivation tend to purposefully influence others by engaging in accountable activities for impression management) (Grant \& Mayer, 2009). However, military norms require soldier to obey orders. In an organization setting, understanding the motivations of subordinates who perform tasks with supervisors or colleagues every day, especially in the process of downsizing of a military organization, is difficult. As no research has explored the motives of "good soldiers" or "good actors" who gain achievements in their career in the re-engineering process, the goal of this study is to address this important yet relatively understudied issue.

Voice behavior is a challenging promotive citizenship behavior that emphasizes the expression of constructive challenge intended to improve and help the organization face a dynamic environment ( $\mathrm{Ng} \&$ Feldman, 2015; Van Dyne \& LePine, 1998). However, some researchers found that employees assess whether or not speaking up, which constructively challenges the status quo, is likely to be effective as well as the risks associated with the potential negative outcomes (Morrison, 2011). Morrison (2011) discussed employees' motivation that highlights the link between effort and expectancy beliefs, which could overcome the problems with risks and inefficacy. Snell and Wong (2007) distinguished between good soldiers and good actors using prosocial motives and impression management motives. With the model of employee voice, we focused on employees' altruistic motivation for helping others or egoistic motivation for impression management. 


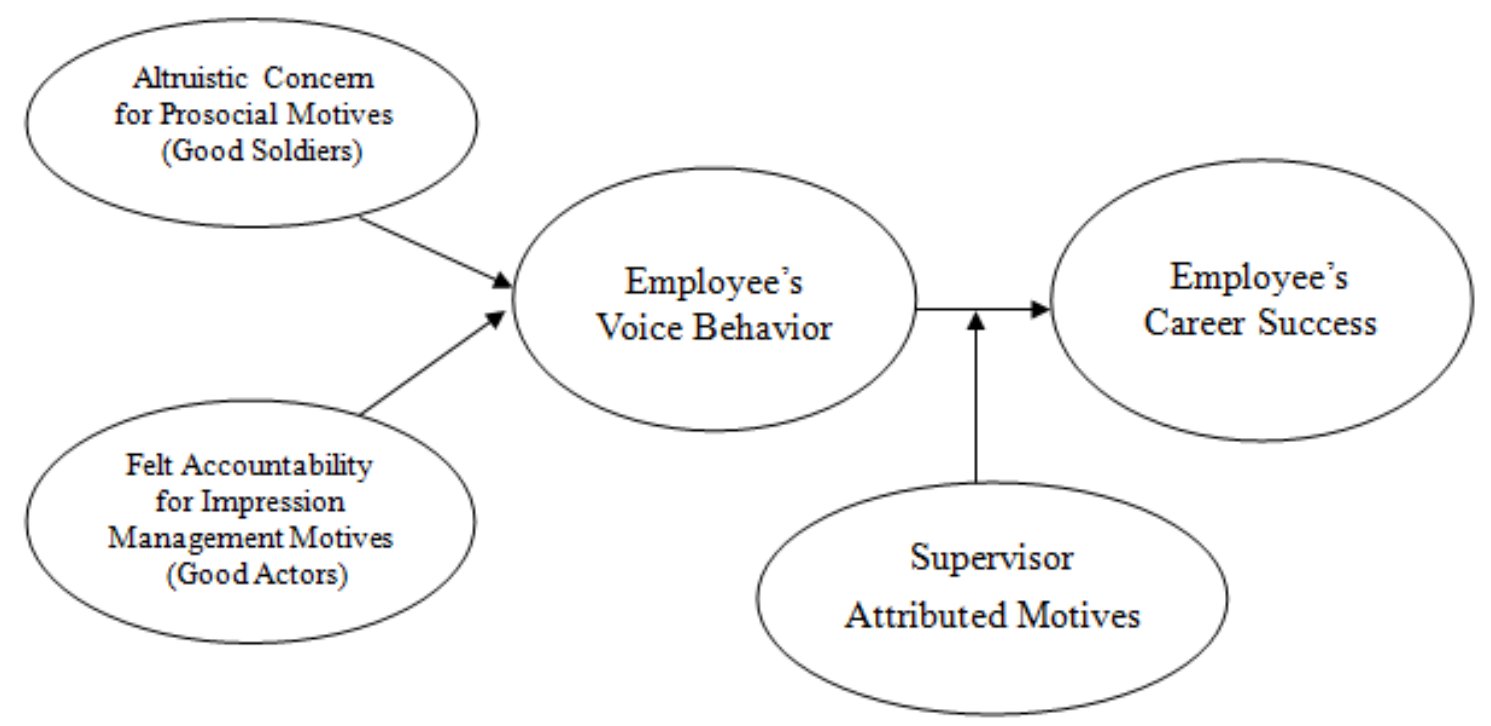

Figure 1. Model Proposed in this Study

The military is a special employment in society. It emphasizes rigid discipline, absolute compliance, paternalistic leadership, institutional orientations (traits of activism and volunteerism), self-value for education, and the prerequisite of service and sacrifice. Therefore, supervisor attribution is an important factor in military promotion. AVF career success is obtained largely from supervisors' support when the promotion committee evaluates candidate ability and work experience, and the direct supervisor recommends the subordinate, whose motivation to perform the task is sufficient for promotion. We attempt to gain a greater understanding of the mechanism of employee voice in career success and address how to attribute the motivation assessed by direct supervisors.

In an attempt to respond to and further contribute to this line of voice behavior research ( $\mathrm{Li} \&$ Sun, 2015; Janssen \& Gao, 2013), especially in a military setting, this paper develops a model delineating the relationship between the motives of voice behavior and employees' career success. Figure 1 presents the theoretical framework of this study.

The model proposed in this study argues that the relationship between employees' motives and career success depends on voice behavior mediating mechanism and the moderating effect of supervisor-attributed motives on the relationship between voice behavior and career success.

\section{Theory and Propositions}

\subsection{Altruistic Concern for Prosocial Motives and Felt Accountability for Impression Management Motives}

Individuals seek to align their behaviors, self-conceptions, and motivations with appropriate goals or standards (Brockner \& Higgins, 2001). The most widely used framework to discuss egoistic and altruistic motivations for prosocial behavior (e.g. engaging in voice) is Batson's (1991) theory (Lemmon, \& Wayne, 2015). Batson (1991), which identifies two underlying drivers of prosocial behavior: egoistic motivation and altruistic motivation. Egoistic motivation refers to the state in which the ultimate goal is increasing one's own welfare (e.g., felt accountability for impression management), whereas altruistic motivation refers to the state in which the ultimate goal is increasing another's welfare (e.g., altruistic concern for supervisors).

We examined the motivations for voice among supervisors. The core of this research is the debate over altruistic and egoistic motivations. Altruistic concern for prosocial motives recognizes the motives of good soldiers, defined as individuals who want to place the needs and welfare of the others above those of the self, thus resulting in the observed prosocial behavior (Friedland \& Cole, 2013; Batson, Lishner, \& Stocks, 2015). Altruistic concern is the voluntary action to help another person who has a work problem and cannot procure on his own, and it can promote interpersonal relationships and organizational performance (Organ, 1988). Moreover, altruistic motives focus on the interests of others and self-sacrifice (e.g., well-being, welfare, and helping), including empathy for others, voice to supervisors, and moral principle.

Egoistic motives present more interest in one's own benefits, and it focuses on the concept of self-serving, which includes self-goal through a group, seeking social approval, and fulfilling social obligations (Bolino, 1999; Li, Kirkman \& Porter, 2014; Laird, Harvey \& Lancaster, 2015). Therefore, felt accountability for impression management motives, identified as the motives of good actors, is an appropriate concept for self-serving motives. The self-serving motive is the implicit or explicit expectation that one's decisions or actions will be subject to evaluation by some salient audience(s), and it is the belief in the potential for either rewards or sanctions based on this expected evaluation 
(Desai \& Kouchaki, 2015; Hall, Frink, Ferris, Hochwarter, Kacmar \& Bowen, 2003). According to definition, individuals are likely to speak out because they expect to gain rewards or sanctions after making a good impression, and individuals use these perceived role expectations to shape their attitudes and guide their behavior.

\subsection{Voice Behavior and Career Success}

Early researchers focused on voice as criticism reacting to individual dissatisfaction (Hirschman, 1970). Recent research on voice behavior has emphasized the expression of constructive challenge intended to improve rather than merely criticize (Venkataramani \& Tangirala, 2010). Within this research stream, scholars have generally focused on the "positive" voice, which improves existing work practices and procedures to benefit organizations. Specifically, voice behavior is viewed as a form of organizational citizenship behavior (OCB) (LePine \& Van Dyne, 2001; Seibert, Kraimer \& Crant, 2001; Van Dyne \& LePine, 1998).

Van Dyne and LePine (1998) defined voice behavior as a promotive citizenship behavior that highlights the expression and communication of constructive challenges aimed at improving situations. However, voice is not formally part of an employee's formal job duties. Nevertheless, it is still important to the operation of the organization and is often used in evaluating employee performance.

Career success describes individual work experiences that result in the accumulation of both positive work-related and psychological outcomes (Chiu, Cheng \& Cheung, 2014; Judge, Cable, Boudreau \& Bretz, 1995; Verbruggen, Van Emmerik, Van Gils, Meng \& de Grip, 2015). Consequently, career success can be classified as either objective or subjective. Objective career success, known as extrinsic career success, involves tangible and quantifiable indices of career accomplishment, such as salary or promotions (Allen, Eby, Porter, Lentz \& Lima, 2004; Singh, Ragins \& Tharenou, 2009). Conversely, subjective career success, known as intrinsic career success, involves affective, evaluative, and attitudinal indices, such as career satisfaction, advancement expectations, or turnover intentions (Chiu, Cheng \& Cheung, 2015; Allen, et al., 2004; Singh, et al., 2009).

OCB is expected to be correlated with career success (Chiu, Cheng \& Cheung, 2015). First, organizations need and value employees who are willing to exceed in their formal job requirements. Empirical studies have found that OCB favorably influences the determination of individual deservedness of organizational rewards (Heilman \& Chen, 2005) and significantly affects decisions that influence their career success (Podsakoff, Mackenzie, Paine \& Bachrach, 2000). Employees can voluntarily improve their knowledge, skills, and abilities to better contribute to their organizations. Second, researchers have argued that OCB is a valuable instrument for achieving desired goals (Yun, Takeuchi \& Liu, 2007). Its discretionary nature enables OCB to give individuals autonomy in their behaviors, thus suggesting that their desires will be more evident with OCB than without it (Chiu, Cheng \& Cheung, 2015). In sum, the relationship between voice behavior and career success is supported.

\subsection{Voice Behavior as Mediator}

To explore the mechanism of employee voice, how altruistic concern for prosocial motives and felt accountability for impression management motives affect career success should be determined. First, we expect that altruistic concern and felt accountability are positively related to employee voice and that employee voice is positively related to career success. That is, voice behavior mediates the relationship between altruistic concern for prosocial motives/felt accountability for impression management motives and career success.

Career success includes extrinsic indicators, which refer to objectively observable career accomplishments such as salary and the number of promotions, and intrinsic indicators, which are employees' own subjective feelings of accomplishment and reflect satisfaction with the rate of progress one is making toward personal career goals and aspirations (Seibert, Kraimer \& Crant, 2001). However, organization downsizing means scarce promotional opportunities and measurement errors (Ettington, 1997). In addition, employees with high career satisfaction mean good feelings of accomplishment and satisfaction with their career and unwillingness to leave the organization. The reason is that employees understand the organization broadly and provide efficient suggestions that gain identification and trust from supervisors or co-workers (Kunst \& Soeters, 1991; Blau, 1985).

According to previous research, individuals with prosocial motives are stimulated by empathy or a "more other-oriented emotional response elicited by and congruent with the perceived welfare of someone else" (Lemmon \& Wayne, 2015). Finkelstien (2009) reported a positive association between prosocial motives and volunteerism, which is ongoing, planned, and discretionary prosocial behavior that benefits non-intimate others and offers little or no tangible reward (Frieder, Hochwarter, \& DeOrtentiis, 2015; Gebauer, Sedikides, Leary \& Asendorpf, 2015). Conversely, individuals' felt accountability means creating an image with implicit or explicit expectation. Empirical studies found that individuals' felt accountability for constructive change influences voice behavior because individuals use voice behavior as an instrument for promotion (Hui, Lam \& Law, 2000; Full, Marler \& Hester, 2006). Therefore, different motives may produce the same behavior and affect the goal to achieve. However, previous organization research did not distinguish these motivations clearly as management cannot accurately explain employees' altruistic behavior (Grant \& Mayer, 2009). For example, employees expressed their image in the process of management to meet their social obligations and to help others, but employees may also profit from their motivation to show the same behavior. In 
summary, we suggest that individuals' motivation influences their career success through voice behavior. The following propositions are presented:

Proposition 1a: Voice behavior mediates the relationship between altruistic concern and career success.

Proposition 1b: Voice behavior mediates the relationship between felt accountability and career success.

\subsection{Moderating Role of Supervisor-attributed Motives}

Researchers have stated that subordinates who engage in OCBs are considered good organizational citizens, but the relationship is moderated by supervisor attributions of motives (Bolino, 1999). Subordinates should consider clearly the motive before voice behavior, that is, whether it is assessed as a prosocial motive in which the supervisor interprets the behavior of the employee as beneficial to others and the organization, or as an impression management motive in which the supervisor views the behavior of the subordinate as ingratiating and conspicuous, and believes that the subordinate's intention is to convey and enhance a positive public image (Grant, 2008; Lam, Huang \& Snape, 2007). This idea also has empirical support. For example, Lam et al. (2007) found that supervisor-attributed impression management motives completely change the relationship between subordinates' feedback-seeking behavior and leader-member exchange quality with supervisors. Similarly, Cheng, Lu, Chang, and Johnstone (2013) suggested that supervisor-attributed prosocial motives strengthen voice behavior in leader-member exchange. Therefore, to examine how supervisor interpretations of their employees' motives for voice behavior affect career success, the following propositions are presented:

Proposition 2a: Supervisor-attributed altruistic concern for prosocial motives moderates the relationship between voice behavior and career success so that the relationship is stronger for supervisors who perceive higher levels of altruistic concern for prosocial motives.

Proposition 2b: Supervisor-attributed felt accountability for impression management motives moderate the relationship between voice behavior and career success, so that the relationship is weaker for supervisors who perceive higher levels of felt accountability for impression management motives.

\section{Theoretical and Managerial Implications}

The results of the current study have important implications for organizational researchers in the Taiwan military as well as for voice researchers and practitioners. The study makes two incremental and unique contributions to the existing literature. First, we extend previous literature on voice behavior to propose a theoretical model highlighting the mediating mechanism in voice behavior between motives and career success. The results provide new and deeper insights into voice behavior by strengthening the role of employee motivations. Second, supervisor attribution motives in examining voice behavior are not yet fully understood in the exchange relationship process. To fill the gap, this paper investigates supervisor attribution of the moderator role in examining voice and career success. The results provide the importance of the context of supervisor attribution motives in linked voice behavior and career success. Overall, our model attempts to address these concerns by highlighting in particular the role of the perspective of supervisor attribution motives to advance the body of knowledge about voice behavior and career success.

The major managerial implication of this study is for supervisors to understand how to assess motives accurately. Attribution biases are most likely to distort perceptions in ambiguous situations. Martinko (2002) suggested that managers should attempt to remove as much ambiguity from work situations as possible. We suggest that training programs can be arranged to teach supervisors how to communicate properly and to avoid biased interpretation of the motives behind employee voice behavior.

\section{REFERENCES}

[1] Allen, T. D., Eby, L.T., Poteet, M. L., Lentz, E., \& Lima, L. (2004). Career benefits associated with mentoring for protégeé: A meta-analysis. Journal of Applied Psychology, 89: 127-136.

[2] Batson, C. D. (1991).The altruism question: Toward a social-psychological answer. Hillsdale, NJ: Erlbaum.

[3] Batson, C. D., Lishner, D. A., \& Stocks, E. L. (2015). 13 The Empathy-altruism hypothesis. The Oxford Handbook of Prosocial Behavior, 259.

[4] Blau, G. J. (1985). The measurement and prediction of career commitment. Journal of occupational Psychology, 58(4), 277-288

[5] Bolino, M. C. (1999). Citizenship and impression management: Good soldiers or good actors?. Academy of Management Review, 24(1), 82-98.

[6] Brockner, J., \& Higgins, E. T. (2001). Regulatory focus theory: Implications for the study of emotions at work. Organizational behavior and human decision processes, 86(1), 35-66.

[7] Cheng, J. W., \& Su, T. W. (2013). Career plateauing and institutional/occupational intention for Taiwanese career officers. Military Psychology, Vol. 25, No. 2, 156-165.

[8] Cheng, J. W., Lu, K. M., Chang, Y. Y., \& Johnstone, S. 
(2013). Voice Behavior and Work Engagement: The Moderating Role of Supervisor-Attributed Motives. Asia Pacific Journal of Human Resources, 51, 81-102.

[9] Chiu, W. L., Cheng, J. W. \& Cheung, Y. H. (2014). Do self-promotion tactics succeed or backfire? Self-promotion tactics, role ambiguity, supervisor-subordinate guanxi and career outcomes. 2014 Management Theory and Practice Conference, Conference Theme: Frontiers of Management: An Asia Pacific Perspective. Hosted by College of Management, National Taiwan University (NTU), Taiwan; Graduate School of Management, Kyoto University, Japan; NTU Business and Accounting Foundation of Culture and Education.

[10] Chiu, W. L., Cheng, J. W. \& Cheung, Y. H. (2015). Obstacles or Benefits: Interactive effects of role ambiguity and organizational citizenship behavior on career success (working paper).

[11] Desai, S. D., \& Kouchaki, M. (2015). Work-report formats and overbilling: How unit-reporting vs. cost-reporting increases accountability and decreases overbilling. Organizational Behavior and Human Decision Processes, 130, 79-88.

[12] Detert, J. R. \& Burris, E. R. (2007). Leadership behavior \& employee voice: Is the door really open? Academy of Management Journal, Vol. 50, pp. 869-884.

[13] Ettington, D. R. (1997). How human resource practices can help plateaued managers succeed. Human Resource Management, 36(2), 221-234.

[14] Finkelstien, M. A. (2009). Intrinsic vs. extrinsic motivational orientations and the volunteer process. Personality and Individual Differences, 46(5), 653-658.

[15] Friedland, J., \& Cole, B. M. (2013). Expanding the motivations for altruism: A philosophical perspective. Journal of Organizational Behavior, 34(8), 1202-1206.

[16] Frieder, R. E., Hochwarter, W. A., \& DeOrtentiis, P. S. (2015). Attenuating the negative effects of abusive supervision: The role of proactive voice behavior and resource management ability. The Leadership Quarterly, 26(5), 821-837.

[17] Fuller, J. B., Marler, L. E., \& Hester, K. (2006). Promoting felt responsibility for constructive change and proactive behavior: Exploring aspects of an elaborated model of work design. Journal of Organizational Behavior, 27(8), 1089-1120.

[18] Gebauer, J. E., Sedikides, C., Leary, M. R., \& Asendorpf, J. B. (2015). Lay beliefs in true Altruism versus universal egoism. Character: New Directions from Philosophy, Psychology, and Theology, 75 .

[19] Grant, A. M. (2008). Does intrinsic motivation fuel the prosocial fire? Motivational synergy in predicting persistence, performance, and productivity. Journal of applied psychology, 93(1), 48.

[20] Grant, A. M., \& Mayer, D. M. (2009). Good soldiers and good actors: prosocial and impression management motives as interactive predictors of affiliative citizenship behaviors. Journal of Applied Psychology, 94(4), 900.

[21] Guan, Y., Zhou, W., Ye, L., Jiang, P., \& Zhou, Y. (2015). Perceived organizational career management and career adaptability as predictors of success and turnover intention among Chinese employees. Journal of Vocational Behavior, $88,230-237$.

[22] Hall, A. T., Frink, D. D., Ferris, G. R., Hochwarter, W. A., Kacmar, C. J., \& Bowen, M. G. (2003). Accountability in human resources management. New Directions in Human Resource Management, 29-63.

[23] Heilman, M. E., \& Chen, J. J. (2005). Same Behavior, different consequences: Reactions to men's and women's altruistic citizenship behavior. Journal of Applied Psychology, 90: 431-441.

[24] Hui, C., Lam, S. S., \& Law, K. K. (2000). Instrumental values of organizational citizenship behavior for promotion: a field quasi-experiment. Journal of Applied Psychology, 85(5), 822.

[25] Janssen, O., \& Gao, L. (2013). Supervisory responsiveness and employee self-perceived status and voice behavior. Journal of Management, 41(7), 1854-1872.

[26] Judge, T. A., Cable, D. M., Boudreau, J. W., \& Bretz, R. D. (1995). An empirical investigation of the predicators of executive career success. Personnel Psychology, 48: 485-519.

[27] Kunst, P., \& Soetens, J. (1991). Works council membership and career opportunities. Organization studies, 12(1), 075-93.

[28] Laird, M. D., Harvey, P., \& Lancaster, J. (2015). Accountability, entitlement, tenure, and satisfaction in Generation Y. Journal of Managerial Psychology, 30(1), 87-100.

[29] Lam, W., Huang, X., \& Snape, E. D. (2007). Feedback-seeking behavior and leader-member exchange: do supervisor-attributed motives matter? Academy of Management Journal, 50(2), 348-363

[30] Lemmon, G., \& Wayne, S. J. (2015). Underlying Motives of Organizational Citizenship Behavior Comparing Egoistic and Altruistic Motivations. Journal of Leadership \& Organizational Studies, 22(2), 129-148.

[31] LePine, J. A., \& Van Dyne, L. (2001). Voice and cooperative behavior as contrasting forms of contextual performance: Evidence of differential relationships with Big Five personality characteristics and cognitive ability. Journal of Applied Psychology, 86, 325-336.

[32] Li, Y., \& Sun, J. M. (2015). Traditional Chinese leadership and employee voice behavior: A cross-level examination. The Leadership Quarterly, 26(2), 172-189.

[33] Li, N., Kirkman, B. L., \& Porter, C. O. (2014). Toward a model of work team altruism. Academy of Management Review, 39(4), 541-565

[34] Martinko, M.J. (2002) Thinking like a winner: A guide to high performance leadership. Tallahassee, FL: Gulf Coast Publishing.

[35] McGovern, P., Hope-Hailey, V., \& Stiles, P. (1998). The managerial career after downsizing: case studies from the 'leading edge'. Work, Employment and Society, 12(03), 457-477

[36] Meese, M. J. (2002). The army officer corps in the all-volunteer force. Contemporary Economic Policy, 20(2), 101-110.

[37] Morrison, E. W. (2011). Employee voice behavior: 
Integration and directions for future research. Academy of Management Annals, Vol. 5, pp. 373-412.

[38] Ng, T. W. H., \& Feldman, D. C. (2015). Idiosyncratic deals and voice behavior. Journal of Management, 41(3), 893-928.

[39] Organ, D. W.(1988). Organizational citizenship behavior: The good soldier syndrome. Lexington, MA: Lexington Books.

[40] Podsakoff, P. M., MacKenzie, S. B., Paine, J. B., \& Bachrach, D. G. (2000). Organizational citizenship behaviors: A critical review of the theoretical and empirical literature and suggestions for future research. Journal of Management, 26: 513-563.

[41] Seibert, S. E., Kraimer, M. L., \& Crant, J. M. (2001). A longitudinal model linking proactive personality and career success. Personnel psychology, 54(4), 845-874.

[42] Seibert, S. E., Kraimer, M. L., \& Crant, J. M. (2001). What do proactive people do? A longitudinal model linking proactive personality and career success. Personnel Psychology, 54: 854-874.

[43] Singh, S., Ragins, B. R., \& Tharenou, P. (2009). What matters most? The relative role of mentoring and career capital in career success. Journal of Vocational Behavior, 75: 56-67.
[44] Shen, Y., Demel, B., Unite, J., Briscoe, J. P., Hall, D. T., Chudzikowski, K., \& Fei, Z. (2015). Career success across 11 countries: implications for international human resource management. International Journal of Human Resource Management, 26(13).

[45] Snell, R. S., \& Wong, Y. L. (2007). Differentiating good soldiers from good actors. Journal of Management Studies, 44(6), 883-909.

[46] Van Dyne, L., \& LePine, J. A. (1998) . Helping and voice extra-role behaviors: Evidence of construct and predictive validity. Academy of Management Journal, 41(1): 108-119.

[47] Venkataramani, V., \& Tangirala, S. (2010). When and why do central employees speak up :An examination of mediating and moderating variables. Journal of Applied Psychology, 95, 582-591.

[48] Verbruggen, M., Van Emmerik, H., Van Gils, A., Meng, C., $\&$ de Grip, A. (2015). Does early-career underemployment impact future career success? A path dependency perspective. Journal of Vocational Behavior, 90, 101-110.

[49] Yun, S., Takeuchi, R., \& Liu, W. (2007). Employee self-enhancement motives and job performance behaviors: Investigating the moderating effects of employee role ambiguity and managerial perceptions of employee commitment. Journal of Applied Psychology, 92: 745-736. 